\title{
Analysis on the Difference and Development of Real Estate in China and the United States
}

\begin{abstract}
Yiming Zhang
Camden Catholic high school in Cherry Hill, New Jersey 08002, America

Email: jonathanzhang0617@gmail.com

ABSTRACT

Differences in the development of the real estate market can reflect differences in national policies. Therefore, it is very important to understand the real estate industry in different countries. Some people buy houses in other countries as investment or face a serious housing price problem in China. People also have to think about the fact that real estate in China is in a stressful situation. Besides, unfamiliarity with the law and unspoken rules in the country are all reasons why people struggle to buy a house. Research has found that domestic real estate is relatively stable and still under development

China's economic growth momentum has been strong in recent years. Externally, the worst is over for the world economy. If the world economy picks up, China's imports and exports will pick up further. In the domestic environment, government momentum is not waning and market momentum is recovering. Therefore, the macroeconomic development situation is so, the real estate market is no exception.
\end{abstract}

Keywords: City and village, the development of real estate, house price increase, occupancy rate, mortgage

\section{INTRODUCTION}

People must be familiar with the word "real estate". So what does the real estate industry specifically include? You may not know much about it. Real estate is in fact the joint name of real estate and real estate, also called real estate, which includes land and buildings and other land fixtures. In a broad sense, real estate refers to land. In a broad sense, real estate refers to land and its permanent buildings, infrastructure, water, mineral resources and other natural resources. The narrow definition of real estate refers only to the permanent buildings on the land and the ownership derived from them. In this paper, it mainly refers to the real estate in narrow sense, which is permitted by the national policy and allowed for individual investment.

The real estate industry is the product of the development of commodity economy, which develops and expands with the development and expansion of commodity economy. In China, taking the real estate industry as an economic sector, carrying out various business activities and establishing the real estate market only began after the implementation of the economic restructuring. The purpose of this paper is to analyze the possible reasons for the development of the real estate industry and the differences caused by cultural factors, and to discuss how the increase in its price affects the general population. It is hoped that the study will raise public awareness of the development of real estate and help those who do not understand the cultural differences in real estate, and a guide for anyone struggling to decide where to buy a house.

\section{CHINA'S REAL ESTATE ECONOMY AND ITS DEVELOPMENT TREND}

There are rational elements and irrational elements behind China's soaring housing prices. The reasonable components of rising house price include: the economic structural transformation and urbanization as the primary driving forces of real estate demand; the consumption upgrading increasing the demand for real estate in big cities; residential mortgages supporting housing demand; the "miniaturization" of family structure driving up the demand for real estate. China has a long period of rising demand for property, but supply is deducing and oversupply is slowly emerging. China's property market has changed from a crowded seller's market to a sparsely populated buyer's one. For a long time in the past, in China's real estate market, developers make money when they buy land, buyers make money when they buy houses, and governments make money when they sell land". However, in the 
future, the era when all participants make money will become a thing of the past, because there is no market for prices and the housing rate is also declining. Moreover, the real estate industry is increasingly divided into more and more detailed, residential, office, commercial areas are more and more obvious. In recent years, with the development of China, the rapid growth of the domestic real estate industry has been promoted. At the same time, the housing price problem that affects the improvement of workers' living standard has also appeared. Residential product was used, consumed, but in the current investment under the condition of scarce, real estate investment properties and speculative property is in slowly emerging, leading to the deformity of the speculation, and when the real estate or belong to the goods, with the continuous development of the market, residential investment has been deteriorating.

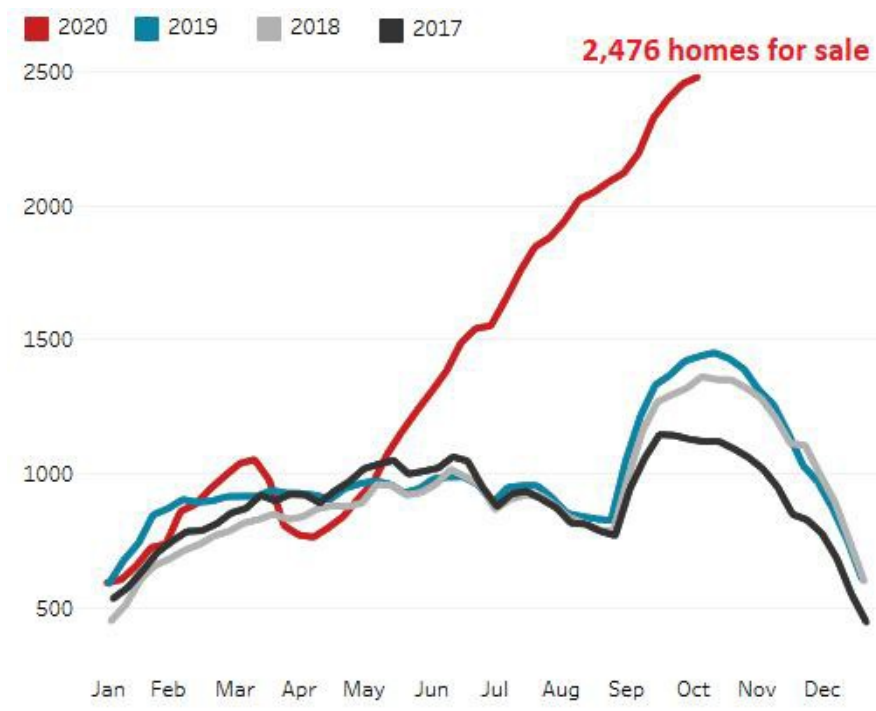

Figure 1. Active Listing in San Francisco Country, CA [7]

\section{HOUSING ECONOMY IN U.S. AND ITS STABILITY}

America's housing market has been one of the best developed markets overseas in recent years, and also is the first country chosen by people to buy and invest in real estate. After a few years of development, the Real estate industry in the United States has developed quite well. According to Realty.com, the U.S. housing market actually strengthened between 2017 and 2020 . America's housing market is expected to get better over the next few years. (1.2) In the United States, the trend of the real estate market since 2015 is still on the hot rise. In the United States, New York, San
Francisco, Chicago, Los Angeles and other areas have seen relatively rapid growth, with an annual increase rate of housing price of about $12 \%$. Commercial real estate price in the United States is $18 \%$ higher than in 2014, and for the best properties in America's financial district, prices are still rising by $70 \%$. The American real estate market follows the rules of the market, suitable for cash when rising, suitable for investment when retracting, and suitable for replacement when stable. As a long-term and stable way of asset appreciation, real estate investment should be faced with a calm and rational attitude by investors in different stages of the market and seek opportunities in the changes.

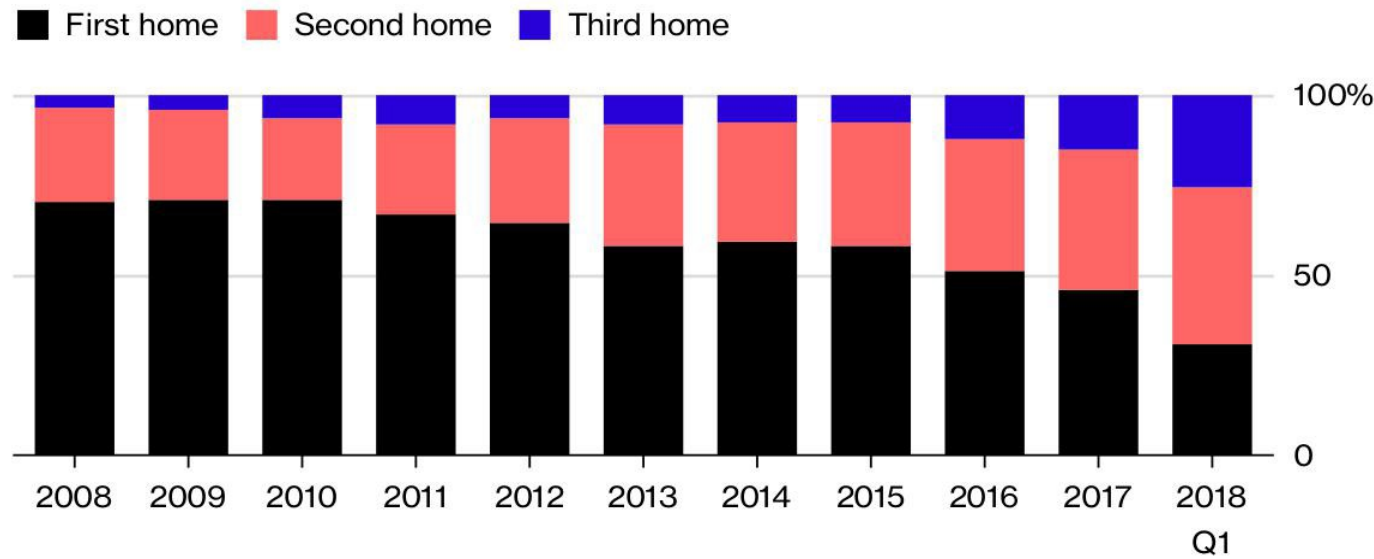

Figure 2. Third-home purchases swell to record proportion of homebuys[8] 


\section{THE CULTURAL AND GEOGRAPHICAL COGNITIVE DIFFERENCES OF CHINESE AND FOREIGN REAL ESTATE}

The Real estate industry in the United States has been around for more than a hundred years and has many well-established systems. All transactions have to go through a regulatory company called a property company. In the process of buying and selling houses, there are a number of third parties to assist in business process, including the housing evaluation company, the companies for real estate transfer notarization, the bank, the loan company and property insurance companies, etc., and each institution plays a different role to ensure that the real estate transaction is fair and reasonable. In China, the process of house transactions also needs to optimization. Although China's housing industry also has undergone great reform, there are still big problems both in the intermediary process and in the transaction process. The government's control over the economy at different times also affects the housing market, causing it to drift. China and the United States differ in the degree of disclosure of real estate data. As things stand, there is a lack of unified official data on global housing prices in China, but in the United States, all real estate data and transaction information are transparent. In the United States, there is a system of listings that can find all the listings for sale. However, real estate brokers or intermediary companies in China only promote their own real estate resources, which are not as transparent as those in the United States. As a result, real estate information in China has great limitations.

In China, to buy a house means to buy an apartment or a new house, but in the United States, it generally means to buy a second-hand or separate house. There are seven types of apartments in the US, with the exception of apartments, which are rented but not sold. Everything else is property, which includes buildings as well as land, and has a permanent title and free use. People in China have only the right to use the house, but not the right to own the land. The term of use is usually 50-70 years.

In China, cities and villages are two different things. A Chinese city is more like a commercial gathering place, where the configuration and resources are abundant. A large number of people swarm into the city and live in a small space. In the United States, there is no absolute distinction between urban and rural. A small American village is more like a satellite town, and each village is surrounded by residential areas with abundant commercial facilities, shops, restaurants, schools, hospitals and so on. So people don't need to go downtown, and staying in their own area can fit their needs. The central cities of America are small areas where people go to work in the morning and go back to the small village where they live in the evening.
Due to the differences between Chinese and American cultures, there are many different understandings and "unspoken rules" in many places. Actually refers to a building area of China's real estate area (using the area of the building, wall occupied area and equally Shared area). But the American housing annotation is a pure usable floor area, and the area of real estate in the United States will not be marked per square meter area, so many areas are not within the price. If you include in the price, then the unit price of American house prices much lower than China's.

The United States has a very strict tax collection process. As long as you own a house in the United States, you have to pay an annual real estate tax, which usually ranges from $1 \%$ to $3 \%$. The real estate tax is set according to the local government's plan for each district. Under California's law, for example, property taxes are allowed to rise annually but less. The property tax is the carrying cost of owning a home in the United States, and it also effectively inhibits the behavior of property speculation in the United States. The United States practices federalism, so each state has different standards and they vary greatly. In China, the property tax is levied at the time of a property transaction. Although some big cities have implemented the property tax, it is extremely low, only $1 \%$. It doesn't do anything to stop the speculative behaviors. A third of China's houses are empty, because many people who buy houses in China don't live in them or rent them, and they just wait for house prices to rise before selling them. Combined with the government's efforts to prop up the market, China's housing prices have remained stubbornly high.

Home loans in the United States have a choice of fixed or variable interest rates. Most people will choose a long-term fixed rate, while others will choose a floating rate, so these people will bear the risk of the interest rate rising. In China, however, people choose mortgages, usually at a variable interest rate, and the borrower has to bear the cost of the change in the market.

Crucially, Chinese cities now have restrictions on purchases and loans, but in the United States, there are no restrictions. In the United States, people can live anywhere they want. But in China, you can only buy a house, and work and live in the policy area.

\section{CONCLUSION}

Through comparison analysis, it is found that American real estate has great advantages in financial support, information disclosure and transaction services, which is what we need to learn. It is precisely because of these gaps that the huge potential of China's real estate stock market, financial market and service market can be predicted in the future, because where the developed countries are leading in the direction of 
our efforts and the trend of growth. The speculation in the whole property market is much higher than the demand for buying and selling property. In the future, China's real estate industry will enter a relatively "fair era" from the previous era when it only focused on "efficiency first". The biggest beneficiaries of China's property market over the past decade have been the government, developers and some suburban farmers, but most of the money has been paid by urban ordinary people. Some people who have given up their careers to buy houses have seen their wealth skyrocket. Those who don't have houses can only look at them and sigh. Looking forward to the next decade, the income distribution of the real estate is bound to shift from an extremely unfair state to a fair and improved state. The real estate market will also shift from the single commercial housing market to the dual-track market of "commercial housing and security housing".

\section{ACKNOWLEDGMENT}

When I finished my thesis, I had no peace of mind. Looking back on my years of study, I have received care and help from teachers, classmates and friends around me, and I have gained valuable wealth in my life. First and foremost, I would like to show my deepest gratitude to my teachers and professors. This research was completed under the guidance of my teacher, who gave me guidance and encouragement in the process of topic selection, investigation, statistical analysis and so on. He not only endowed me with rich professional knowledge, but also cultivated my optimistic and positive attitude towards life. The teacher's profound knowledge, rigorous attitude towards learning and personality all let me moved, I will always be worth learning. From the thesis topic selection, opening design to the research of key issues have helped me a lot. I would like to express my heartfelt thanks to all the teachers, classmates and friends for your company and help. I am full of hope and gratitude for my life and future. The completion of my thesis cannot be achieved without you. At the same time, I am also very grateful to my parents and relatives. It is your support and encouragement that make me concentrate on my study.

\section{REFERENCES}

[1] X. Zhao, H. Li. "Six trends of China's real estate development." new Shanxi merchants. (2013): 5659

[2] X. Peng. "Discussion on the development trend of China's real estate." housing and real estate. (2017): $20+38$

[3] China's Real Estate Development Report No.14
(2017)." Economic Trends. (2017): 163.

[4] D. Sun, Z. Ding. China's Real Estate Development Strategy to Adapt to the" New Normal ", Journal of Qingdao Administration College of the CPC Qingdao municipal Party committee. (2015): 40.

[5] L. Ran. Current situation of China's Real Estate Development." New Countryside. (2011):142-142.

[6] S. Dai. Analysis of the Development Trend of China's Real Estate in the Next Ten Years." Housing and Real Estate. (2015):43-46.

[7] F. Derek, 2019, The cost of housing is tearing our society apart,

https://wolfstreet.com/2020/10/23/housing-market-g oes-nuts-everyone-sees-it-but-it-cant-last/

[8] W. Richter, 2020, Housing Market Goes Nuts, Everyone Sees it, But it Can' t Last 